\title{
TRANSPORTASI DAN KETIMPANGAN WILAYAH DI PROVINSI JAWA TIMUR
}

\author{
Jose Rizal Joesoef ${ }^{1}$, Sulistiyanti, Andreas Prasetia \\ Universitas Gajayana \\ e-mail: joserizalj@gmail.com ${ }^{1)}$
}

\begin{abstract}
It is well understood that transportation improves the accessibility and transportation is needed in production and consumption activities. This study is aimed to describe the pattern of the movement of people and goods among districts/cities within the Province of East Java, to estimate the density of people and goods, and to measure the inequality of transport density. This study is also to test whether transport affects welfare. It is found that the Malang District and Surabaya City are the most destination of goods transport. Regression analysis shows that the density of transport only affects the welfare (as measured by the $H D I)$ when together with other variables, namely poverty and GDP/capita. However, partial density of transport has no effect on the welfare.
\end{abstract}

Keywords:Transportation, trip generations, trip attraction, inequality, welfare

\section{PENDAHULUAN}

Provinsi Jawa Timur merupakan salah satu provinsi di Indonesia yang memiliki posisi strategis karena menjadi penghubung antara kawasan barat dan tengah dengan kawasan timur Indonesia. Posisi ini membuat arus lalu lintas barang maupun orang dari kawasan barat ke kawasan timur atau sebaliknya harus melalui wilayah ini. Semakin tingginya mobilitas barang dan orang dari waktu ke waktu mencerminkan semakin intensifnya kegiatan ekonomi yang selanjutnya dapat meningkatkan kesejahteraan masyarakat. Kinerja perekonomian Jawa Timur berdasarkan tahun dasar 2010 pada triwulan II 2015 mencapai 5,3\% (yoy) meningkat dibanding triwulan I 2015 sebesar 5,2\% (BPS, 2015). Pertumbuhan ini lebih tinggi dibandingkan Nasional $(4,7 \%)$ dan Kawasan Jawa $(5,1 \%)$.Akan tetapi, tidak semua daerah di Provinsi Jawa Timur dapat mencapai tingkat kesejahteraan yang tinggi. Kementerian Pembangunan Daerah Tertinggal menyebutkan masih ada 5 kabupaten di Jawa Timur masih tergolong daerah tertinggal, yaitu Bondowoso, Situbondo, Bangkalan, Sampang dan Pamekasan (www.kemenegpdt.go.id/hal/300027).Salah satu faktor yang menyebabkan suatu daerah sulit berkembang adalah kurangnya prasarana dan sarana, termasuk transportasi.

Transportasi dibutuhkan untuk berpindah dan berinteraksi. Interaksi intradaerah maupun antardaerah dibutuhkan karena adanya saling keterkaitan dan ketergantungan pada beberapa aktivitas di zona-zona yang berbeda, misalnya di zona perdagangan, memerlukan pergerakan dan mobillitas barang dari zona industri. Ini dapat menjadi faktor penarik bagi transportasi. Dengan mengidentifikasi pergerakan antardaerah, dapat diketahui pola pergerakan barang dan orang antardaerah. Semakin intensif pergerakan antardaerah, dapat diartikan bahwa semakin tinggi pula tingkat ketergantungan spasial. Intensifnya pergerakan barang dan orang juga bisa diartikan semakin tingginya tingkat aktivitas ekonomi dan selanjutnya berdampak pada tingkat kesejahteraan 
masyarakat.

Tujuan umum yang ingin dicapai dalam penelitian ini adalah mengungkap ada tidaknya kesenjangan transportasi di kabupaten/kota di Provinsi Jawa Timur dan melihat pengaruhnya terhadap kesejahteraan masyarakat. Secara khusus, tujuan yang ingin dicapai adalah: mengukur ketimpangan kepadatan transportasi di kabupaten/kota di Provinsi Jawa Timur; mengukur ketimpangan wilayah di Provinsi Jawa Timur dan memperkirakan pengaruh transportasi terhadap kesejahteraan masyarakat Jawa Timur.

Kajian literatur dalam penelitian ini meliputi: 1) Pembangunan Wilayah dan 2) Keterkaitan, Interaksi Spasial dan Interkoneksi. Pembangunan di suatu wilayah secara administratif dibatasi oleh ruang/space. Umumnya pembatasan wilayah dilakukan secara administratif oleh pemerintah. Di Indonesia, pembagian wilayah administratif dilakukan menurut wilayah provinsi, kabupaten/kota, kecamatan, dan perdesaan/kelurahan. Situasi dan kondisi masing-masing wilayah berbeda satu sama lain, dan tingkat kemajuan dari pembangunan perekonomian juga berbeda.

Adanya perbedaan dalam tingkat pencapaian target-target pembangunan menunjukkan adanya ketimpangan. Beberapa daerah mencapai tingkat kemajuan yang cukup tinggi, di sisi lain beberapa daerah lainnya mengalami keterbelakangan. Ketimpangan ekonomi antar wilayah dapat terjadi karena beberapa hal (Sjafrizal 2012:119-122): 1) Perbedaan kandungan sumber daya alam, 2) Perbedaan kondisi demografis, 3) Kurang lancarnya mobilitas barang dan jasa, 4) Konsentrasi kegiatan ekonomi wilayah, 5) Alokasi dana pembangunan antar wilayah.

Masing-masing daerah memiliki ragam dan kapasitas sumber daya alam yang berbeda. Mengikuti teori Hecksher-Ohlin, suatu daerah akan memiliki keunggulan komparatif pada output/komoditi di mana dalam proses produksinya dilakukan secara intensif terhadap sumberdaya yang berlimpah di daerahnya. Apabila di daerah tersebut memiliki kandungan minyak dan gas alam, maka otomatis daerah tersebut unggul dalam produksi minyak dan gas alam. Daerah yang memiliki kandungan batubara, maka daerah tersebut unggul dalam produksi batubara. Demikian juga dengan daerah yang memiliki iklim dan tanah yang cocok untuk lahan perkebunan kelapa sawit, maka akan unggul dalam produksi kelapa sawit.

Kegiatan produksi yang dilakukan oleh masyarakat menghasilkan produk yang bisa dikonsumsi sendiri (subsisten) ataupun dijual/diperdagangkan. Hasil produksi yang diperdagangkan memerlukan prasarana dan sarana untuk memindahkan barang/output dari lokasi produksi ke lokasi konsumen, distributor, atau pasar. Dalam proses pemindahan produk inilah diperlukan jasa transportasi.

Elemen-elemen dalam sistem transportasi mencakup prasarana jalan/air/udara, sarana moda yang digunakan untuk pengangkutan, sistem lalu lintas, dan tempat tunggu serta tempat pemberhentian. Kegiatan perdagangan merupakan proses penukaran atau transaksi antara penjual dan pembeli. Penjual berkepentingan dengan transportasi dalam memindahkan produk, konsumen berkepentingan dengan transportasi dalam perjalanannya dari lokasi pemukiman ke lokasi penjualan, konsumen juga berkepentingan dengan transportasi dalam perjalanannya untuk bekerja di lokasi produksi barang/jasa dalam rangka memperoleh pendapatan. Sistem transportasi yang efisien akan mempercepat mobilitas manusia dan barang dan mempercepat roda perekonomian. 
Kegiatan ekonomi dapat terkonsentrasi pada wilayah tertentu. Ini disebabkan karena umumnya pengusaha/produsen memilih lokasi produksi yang mendekati konsumen (untuk produksi jasa), mendekati sumber bahan baku atau mendekati tenaga kerja. Kegiatan-kegiatan produksi ini didukung oleh tenaga kerja sebagai faktor produksi, dan bahan-bahan baku yang didatangkan ke lokasi produksi. Aktivitas-aktivitas di titik ini dapat menjadi pusat grafitasi untuk menarik aktivitas-aktivitas lainnya seperti meningkatnya jasa kuliner, jasa transportasi, perdagangan dan komunikasi, sehingga memberikan efek spill-over dan menumbuhkembangkan iklim usaha. Semakin ramainya aktivitas di daerah ini mendorong berkembangnya infrastruktur yang menunjang kehidupan sosial dan ekonomi. Di sisi lain, daerah yang 'sepi' (karena kurang didukung oleh faktor 'endowment' yang cukup), menjadi tertinggal dibandingkan dengan daerah lain yang lebih 'ramai'.

Ketimpangan yang terjadi antar daerah dapat menyulut terjadinya konflikkonflik sosial di antara masyarakat. Wilayah/kawasan hinterland menjadi lemah karena pengurasan sumberdaya yang berlebihan, yang mengakibatkan aliran bersih dan akumulasi nilai tambah tertuju ke pusat-pusat pembangunan secara masif dan berlebihan sehingga terjadi akumulasi nilai tambah di kawasankawasan pusat pertumbuhan (Rustiadi dkk, 2011:223).

Menurut Rustiadi ketidakseimbangan inter-regional di Indonesia diatasi dengan berbagai program pengembangan wilayah/kawasan. Strategi untuk pengembangan wilayah ini dapat dilakukan dengan strategi sisi pasokan (supplyside strategy), yakni berupa program-program pengembangan kawasan yang didasarkan atas keunggulan-keunggulan komparatif, berupa upaya-upaya peningkatan produksi dan produktivitas kawasan (Rustiadi dkk, 2011:224). Akan tetapi strategi dengan pendekatan pasokan ini seringkali terhambat oleh adanya keterbatasan sisi permintaan (demand trap) baik secara domestik maupun dari luar wilayah/kawasan. Untuk itu, strategi pembangunan kawasan juga harus dikembangkan melalui upaya-upaya mendorong tumbuhnya permintaan.

Selain sisi pasokan dan permintaan, strategi pembangunan kawasan harus didasarkan atas prinsip strategi sinergi keterkaitan (linkages) antar kawasan. Strategi berbasis keterkaitan antar kawasan pada awalnya dapat diwujudkan dengan mengembangkan keterkaitan fisik antar kawasan melalui pembangunan berbagai infrastruktur fisik (jaringan transportasi jalan, pelabuhan, jaringan komunikasi, dan lain-lain) yang dapat menciptakan keterkaitan fisik antar kawasan.

Sementara itu menurut Sjafrizal, kebijakan dan upaya untuk menanggulangi ketimpangan ekonomi antar wilayah sangat ditentukan oleh faktor yang menentukan terjadinya ketimpangan tersebut. Untuk mengurangi ketimpangan ekonomi antar wilayah, hal-hal yang dapat dilakukan antara lain(Sjafrizal 2012:123-126); 1) Penyebaran pembangunan prasarana perhubungan, 2) Mendorong transmigrasi dan migrasi spontan, 3) Pengembangan pendidikan antar wilayah, 4) Pengembangan pusat pertumbuhan, 5) Pelaksanaan otonomi daerah.

Pembangunan prasarana perhubungan perlu dilakukan untuk meningkatkan aksesibilitas yang dapat menjangkau seluruh wilayah bahkan yang berada di pelosok. Aksesibilitas ini mendorong kelancaran mobilitas faktor-faktor produksi, tenaga kerja maupun hasil produksi antar daerah dan dapat memancing investasi. Diharapkan prasarana perhubungan dapat mendorong berkembangnya perekonomian daerah dan mengurangi ketimpangan regional. 
Sementara itu dalam keterkaitan, interaksi spasial dan interkoneksi, keterkaitan spasial bisa terbentuk karena banyak kepentingan, baik kepentingan ekonomi, sosial, budaya, teknologi, informasi, politik, hukum, ataupun pertahanan dan keamanan. Misalnya dalam kegiatan produksi, produsen memroses input menjadi output. Input didatangkan dari berbagai sumber bahan baku dan tenaga kerja, yang mungkin berlokasi di lain tempat. Modal mungkin juga perlu didatangkan dari lokasi lain. Setelah input diproses dan menjadi output, maka perlu didistribusikan ke lokasi distribusi. Keterkaitan antar lokasi ini menimbulkan adanya interaksi spasial.

Menurut Rustiadi dkk, interaksi antar dua tempat dipengaruhi oleh besarnya aktivitas sosial dan aktivitas ekonomi serta jarak di antara dua tempat tersebut. Interaksi spasial dapat berupa migrasi, fenomena menglaju (commuting), frekuensi percakapan telepon, aliran surat melalui jasa kantor pos, aliran barang dan jasa, aliran uang dan sebagainya (Rustiadi dkk, 2009:288). Terjadinya interaksi spasial dapat dibedakan menjadi 3 hal; (1) faktor pendorong (push factors), (2) faktor daya tarik (pull factors) dan (3) faktor jarak. Faktor pendorong berasal dari titik awal, yaitu faktor-faktor yang menggerakkan manusia atau barang menuju ke tempat lain. Sebaliknya faktor daya tarik berada pada lokasi tujuan, yaitu faktor-faktor yang mempengaruhi orang atau barang untuk datang ke lokasi tersebut. Lokasi titik awal dengan lokasi titik tujuan dihubungkan dengan jarak. Semakin jauh jarak antara kedua lokasi, interaksi spasial semakin kecil, dan sebaliknya semakin dekat jarak antara kedua lokasi, interaksi spasial semakin besar.

Interaksi spasial merupakan bagian dari linkage (keterkaitan) antar wilayah, disamping aliran/flow barang dan manusia. Interaksi spasial dapat terjadi apabila didukung oleh infrastruktur yang dapat menghubungkan antara lokasi yang satu dengan yang lain, sehingga membentuk sebuah jaringan infrastruktur yang saling terkoneksi. Apabila dalam suatu ruang/space belum tercakup dalam jaringan infrastruktur, maka akan menghambat interaksi dengan lokasi lain.

Menurut Rondinelli, elemen-elemen yang terkait dengan keterkaitan fisik adalah jaringan jalan, jaringan transportasi sungai dan air, jaringan kereta api, dan ketergantungan ekologis. Elemen-elemen yang terkait dengan keterkaitan ekonomi adalah pola-pola pasar, arus bahan baku dan barang antara, arus modal, keterkaitan produksi backward, forward dan lateral, pola konsumsi dan belanja, arus pendapatan dan arus komoditi sektoral serta interregional cross linkages. Sistem pelayanan transportasi merupakan salah satu elemen dari keterkaitan delivery pelayanan.

Studi terdahulu yang pernah dilakukan diantaranya Calderon dan Serven (2004) melakukan evaluasi empiris mengenai dampak dari pembangunan infrastruktur terhadap pertumbuhan ekonomi dan distribusi pendapatan dengan menggunakan satu set data panel besar yang mencakup 121 negara selama 1960-2000. Infrastruktur yang dicakup meliputi kuantitas dan kualitas telekomunikasi, listrik, dan jalan. Kuantitas telekomunikasi diukur dengan jumlah sambungan (line), listrik dengan jumlah daya, dan jalan dengan panjang jalan. Sementara kualitas telekomunikasi diukur dengan waktu tunggu saluran sambung, kualitas listrik dengan prosentase transmisi dan hilangnya distribusi terhadap produksi listrik, dan kualitas jalan diukur dengan pangsa jalan yang sudah diaspal terhadap total jalan. Korelasi antara stok infrastruktur secara individual dengan pertumbuhan ekonomi adalah positif, dengan koefisien 0,15 
untuk telekomunikasi, 0,13 untuk listrik dan 0,21 untuk jalan. Di sisi lain, korelasi antara kualitas infrastruktur dengan pertumbuhan ekonomi juga positif; 0,12 untuk telekomunikasi dan listrik, serta 0,17 untuk jalan. Baik dari segi kuantitas maupun kualitas, infrastruktur transportasi mempunyai pengaruh paling besar terhadap pertumbuhan ekonomi dibanding infrastruktur lainnya.

Selain memperkirakan pengaruh infrastruktur terhadap pertumbuhan ekonomi, Calderon dan Serven juga mengukur pengaruh infrastruktur terhadap ketimpangan distribusi pendapatan. Ketimpangan distribusi pendapatan diukur dengan koefisien Gini, yang nilainya antara 0 s/d 1. Koefisien Gini sama dengan 0 berarti distribusi pendapatan merata sempurna, dan koefisien Gini sama dengan 1 berarti ada ketimpangan sempurna. Mereka menemukan bahwa infrastruktur berpengaruh negatif terhadap koefisien Gini. Artinya bahwa pembangunan infrastruktur yang semakin baik akan semakin memperbaiki distribusi pendapatan menuju distribusi yang lebih merata. Pengaruh kuantitas infrastruktur terhadap koefisien Gini ditemukan -0,39 untuk telekomunikasi, -0,44 untuk listrik dan $-0,48$ untuk jalan dan $-0,57$ untuk rel. Sedangkan pengaruh kualitas infrastruktur terhadap koefisien Gini ditemukan -0,34 untuk telekomunikasi, $-0,26$ untuk listrik dan -0,55 untuk transportasi. Hasil temuan ini menunjukkan bahwa infrastruktur transportasi paling berpengaruh terhadap pemerataan distribusi pendapatan dibanding infrastruktur lainnya.

Selanjutnya Calderon (2010) mengungkapkan adanya ketimpangan akses terhadap infrastruktur antar kelompok negara; yaitu kelompok negaranegara industri, Asia Timur, Amerika Latin dan negara-negara berpenghasilan menengah selain Asia Timur. la menemukan bahwa ketimpangan infrastruktur terjadi pada infrastruktur telekomunikasi, transportasi, listrik, air bersih dan sanitasi, baik secara kuantitas mapupun kualitas. Calderon menemukan bahwa akses infrastruktur di negara-negara Amerika Latin relatif berada di bawah kelompok negara lainnya. Akses terhadap fixed telephone, di negara industri mencapai 92,5; Asia Timur 51,8; negara berpenghasilan menengah selain Asia Timur 50,9 dan Amerika Latin 46,6 (hampir setengah dari negara industri). Ketimpangan juga terjadi pada akses transportasi, di mana di negara-negara industri akses transportasi 93,7; Asia Timur 85,3; negara berpenghasilan menengah selain Asia Timur 76; dan Amerika Latin 64,3.

\section{METODE PENELITIAN}

Penelitian ini dilakukan untuk lingkup wilayah Propinsi Jawa Timur dengan fokus pembahasan pada pola pergerakan orang dan barang antarkabupaten/kota. Selanjutnya dianalisis ketimpangan transportasi dan juga ketimpangan ekonomi wilayah, serta memperkirakan pengaruh transportasi terhadap kesejahteraan masyarakat.

Data yang digunakan dalam penelitian meliputi baik data kuantitatif maupun data kualitatif. Data kuantitatif yang digunakan meliputi: Produk Domestik Regional Bruto (PDRB), jumlah penduduk, jumlah penumpang, jumlah muatan barang, panjang jalan, Indeks Pembangunan Manusia (IPM) dan lainlain. Adapun data kualitatif yang digunakan antara lain arah pergerakan muatan barang dan orang dan jaringan jalan nasional. Berdasarkan sumbernya, data yang digunakan adalah berupa data sekunder. Data sekunder yang digunakan dalam penelitian ini dikumpulkan dari berbagai instansi yang terkait antara lain Dinas Perhubungan Provinsi Jawa Timurdan Badan Pusat Statistik (BPS). 


\section{Pola Pergerakan Barang}

Pola pergerakan barang dan penumpang dapat dicermati dengan menggunakan matriks yang disebut sebagai Matriks Asal Tujuan (MAT) atau Origin Destination Matrix (ODM). Matriks Asal Tujuan merupakan matriks bujur sangkar yang dalam penelitian ini berorde 38 , sesuai dengan jumlah kabupaten/kota yang menjadi zona asal dan zona tujuan di wilayah Provinsi Jawa Timur. Sel-sel dalam matriks ini $\left(a_{i j}\right)$ menunjukkan volume pergerakan dari zona asal ke zona tujuan. Zona asal ditunjukkan oleh masing-masing baris $\left(\mathrm{O}_{\mathrm{i}}\right)$ dan zona tujuan ditunjukkan oleh masing-masing kolom $\left(D_{j}\right)$.

Tabel 2

Pola Pergerakan Barang dan Penumpang

\begin{tabular}{cccccc}
\hline $\begin{array}{c}\text { Tujuan } \\
\text { Asal }\end{array}$ & $D_{1}$ & $D_{2}$ & $D_{3}$ & $\ldots$ & $D_{j}$ \\
\hline$O_{1}$ & $a_{11}$ & $a_{12}$ & $a_{13}$ & $\ldots$ & $a_{1 j}$ \\
$O_{2}$ & $a_{21}$ & $a_{22}$ & $a_{23}$ & $\ldots$ & $a_{2 j}$ \\
$O_{3}$ & $a_{31}$ & $a_{32}$ & $a_{33}$ & $\ldots$ & $a_{3 j}$ \\
$\ldots$ & & & & $\ldots$ & $\ldots$ \\
$O_{j}$ & $a_{i 1}$ & $a_{i 2}$ & $a_{i j}$ & $\ldots$ & $a_{i j}$ \\
\hline
\end{tabular}

Zona asal $\mathrm{O}_{i}$ merupakan titik awal pergerakan, yang dapat bergerak ke berbagai tujuan. Zona asal ini menjadi bangkitan perjalanan (trip generation) dari semua yang bergerak dan berjalan dari zona ini. Apabila setiap baris dalam Matriks Asal Tujuan (MAT) dijumlahkan (mendatar), maka akan diperoleh total bangkitan perjalanan yang berasal dari zona di baris ini. Total bangkitan perjalanan ini juga biasa disebut sebagai total trip production.

Zona tujuan (destination) $D_{j}$ adalah lokasi yang menjadi tujuan perjalanan. Perjalanan datang dari berbagai arah bergerak menuju lokasi destinasi. Volume pergerakan menuju lokasi ini tergantung dari potensi dan kemampuan zona ini untuk menarik pergerakan barang maupun orang. Zona tujuan yang semakin menarik dan penting, akan semakin berpotensi untuk didatangi/dikunjungi, misalnya daerah yang memiliki fasilitas umum yang relatif bagus seperti lembaga pendidikan, rumah sakit, pusat perdagangan, pariwisata, dan lain-lain. Daya tarik dari zona tujuan dapat diukur dengan menjumlahkan sel-sel pada setiap kolom secara vertikal pada MAT. Hasil penjumlahan secara vertikal ini menunjukkan total tarikan perjalanan (total trip attraction).

Untuk menggambarkan pola sebaran pergerakan, dilakukan pengurutan secara mendatar (ranking baris) maupun secara vertikal (ranking kolom). Pengurutan dilakukan berdasarkan pada volume muatan terbanyak. Pengurutan dalam setiap baris (ranking baris) menunjukkan urutan tujuan pergerakan muatan terbanyak yang dilakukan dari zona asal baris i. Misalnya ranking 1 pada baris $\mathrm{i}$ menggambarkan bahwa volume pergerakan terbesar dari zona $O_{i}$ berjalan menuju ke zona tujuan yang terdapat pada kolom di mana terdapat ranking 1 tersebut. Ranking ini terbentang dari urutan 1 sampai 38 sesuai dengan jumlah zona pengamatan yaitu kabupaten/kota di Jawa Timur. Ranking baris menunjukkan urutan intensitas pergerakan dari zona asal baris ini ke berbagai tujuan di kolom MAT.

Pengurutan secara vertikal (ranking kolom) menunjukkan urutan intensitas pergerakan dari berbagai sumber pergerakan (zona asal) ke kolom tujuan. Ranking 1 pada kolom $D_{j}$ dapat diartikan bahwa zona asal pada sel yang 
menjadi ranking 1 ini merupakan pemasok utama perjalanan ke zona ini. Dengan mengamati urutan-urutan ini, dapat diketahui pola intensitas pergerakan muatan antar zona (antar kabupaten/kota).

\section{Ketimpangan Transportasi}

Sebelum dilakukan pengukuran terhadap ketimpangan transportasi, terlebih dahulu dilakukan analisis tipologi transportasi daerah kebupaten/kota di Provinsi Jawa Timur. Tipologi transportasi dibedakan menjadi 4 kelompok yang diletakkan pada 4 bidang kuadran berdasarkan pada tingkat kepadatan muatan orang dan barang, yaitu: 1) Kepadatan transportasi barang maupun penumpang tinggi, 2) Kepadatan transportasi barang rendah, namun kepadatan transportasi penumpang tinggi, 3) Kepadatan transportasi barang tinggi, namun kepadatan transportasi penumpang rendah, 4) Kepadatan transportasi barang dan penumpang keduanya rendah.

Selanjutnya dilakukan pengukuran terhadap tingkat ketimpangan transportasi. Pendekatan yang dilakukan untuk mengukur ketimpangan transportasi adalah menggunakan pendekatan Indeks Williamson. Formula Indeks Williamson untuk mengukur kesenjangan adalah sebagai berikut:

$$
V_{w}=\frac{\sqrt{\sum_{i=1}^{n}\left(t_{i}-\bar{t}\right)^{2}\left(\frac{j_{i}}{J}\right)}}{\bar{t}}
$$

Dimana $\mathbf{V}_{\mathbf{w}}=$ Indeks Variasi Williamson, $\mathbf{t}_{\mathbf{i}}=$ Kepadatan transportasi di kabupaten $/$ kota $\mathrm{i}, \overline{\boldsymbol{t}}=$ Kepadatan transportasi rata-rata provinsi, $\mathrm{j}_{\mathrm{i}}=$ Panjang jalan di kabupaten/kota i, J = Panjang jalan di Provinsi Jawa Timur.

Formula ini mengadopsi dari Indeks Williamson yang mula-mula dicetuskan oleh Jeffrey G. Williamson (1966) untuk mengukur ketimpangan pendapatan. Kepadatan transportasi bisa diukur dengan beberapa pendekatan, antara lain rata-rata jumlah kendaraan untuk setiap kilometer panjang jalan, jumlah kendaraan untuk setiap satuan waktu tertentu, ataupun volume muatan pergerakan untuk setiap panjang jalan. Penelitian ini menggunakan pendekatan volume muatan pergerakan rata-rata untuk setiap panjang jalan.

\section{Ketimpangan Wilayah}

Dalam ketimpangan wilayah Analisis Klassen Typology digunakan untuk melihat gambaran tentang pola dan struktur pertumbuhan masing-masing sektor ekonomi. Analisis Klassen Typology mengklasifikasikan daerah berdasarkan pada pencapaian PDRB per kapita dan tingkat pertumbuhan ekonomi daerah. Menurut analisis tipologi daerah, daerah dibagi menjadi 4 klasifikasi, yaitu (Sjafrizal 2012, Kuncoro 2012): 1) Daerah cepat maju dan cepat tumbuh adalah daerah yang memiliki laju pertumbuhan ekonomi dan pendapatan perkapita yanglebih tinggi dari rata-rata wilayah, 2) Daerah maju tapi tertekanadalah daerah yang memiliki pendapatan perkapita yang lebih tinggi, tetapi tingkat pertumbuhan ekonominya lebih rendah dari rata-rata, 3) Daerah berkembang cepat adalah daerah yang memiliki tingkat pertumbuhan tinggi, tetapi tingkat pendapatan perkapita lebih rendah dari rata-rata, 4) Daerah relatif tertinggal adalah daerah yang memiliki tingkat pertumbuhan ekonomi dan pendapatan perkapita yang rendah. 


\section{Pengaruh Transportasi Terhadap Kesejahteraan}

Metode regresi digunakan untuk memperkirakan pengaruh transportasi terhadap tingkat kesejahteraan. Transportasi yang diukur dalam hal ini adalah intensitas muatan barang dan muatan penumpang. Indikator tingkat kesejahteraan yang digunakan adalah IPM (Indeks Pembangunan Manusia). Penggunaan indikator ini disebabkan karena di dalamnya tercakup indeks kesehatan, indeks pendidikan dan indeks pendapatan. Model dicari yang memberikan hasil estimasi terbaik, yaitu yang memberikan kepercayaan tertinggi (dapat dilihat dari koefisien determinasinya).

\section{HASIL DAN PEMBAHASAN}

Adanya pergerakan baik barang maupun orang dari satu wilayah ke wilayah lain menunjukkan adanya ketergantungan spasial antar ruang. Setiap daerah mempunyai potensi dan sumber daya masing-masing. Apabila suatu daerah mengembangkan suatu produk unggulan tertentu, sudah barang tentu daerah tersebut perlu menggunakan jasa transportasi untuk memindahkannya dari lokasi produksi ke distributor atau ke pasar. Produk unggulan di masingmasing daerah akan 'diekspor' ke luar daerah apabila volume produksinya berlebih, dan sebaliknya suatu daerah akan 'mengimpor' produk yang menjadi unggulan daerah lain. Perdagangan dan pergerakan barang ini memerlukan jasa transportasi yang efisien untuk menunjang keberhasilannya dalam mendistribusikan barang.

Muatan barang yang berasal dari zona asal Jawa Timur paling banyak dimuat ke daerah Jawa sendiri dan Pulau Bali. Lima daerah tujuan dengan volume terbanyak berturut-turut adalah: Jawa Tengah, Jawa Barat, Daerah Istimewa Yogyakarta, Bali dan Banten. Sementara Provinsi Jawa Timur menjadi zona tujuan terbesar dari daerah Provinsi Jawa Tengah, Jawa Barat, DI Yogyakarta, Banten dan Sumatera Utara. Dengan demikian terlihat bahwa daerah-daerah provinsi di P. Jawa memiliki hubungan yang cukup kuat. Hal ini menunjukkan adanya ketergantungan spasial di antara mereka. Total muatan yang bergerak dari Jawa Timur menuju provinsi lain (ekspor) sebesar 3.304.806.040 ton. Sebaliknya total muatan yang bergerak dari daerah lain menuju Jawa Timur (impor) sebesar 3.021.217.393 ton. Ini artinya total muatan yang bergerak keluar wilayah lebih banyak dibanding total muatan yang masuk, dengan kata lain ada ekspor neto sebesar 283.588.647 ton. 


\section{Tabel 2}

Total Bangkitan dan Total Tarikan

\begin{tabular}{|c|c|c|c|c|}
\hline No & Kabupaten/Kota & Total Bangkitan & Total Tarikan & Perbedaan \\
\hline 1 & Kab. Pacitan & $15.275 .442,71$ & $16.532 .326,55$ & $(1.256 .883,84)$ \\
\hline 2 & Kab. Ponorogo & $27.183 .164,44$ & $30.074 .129,91$ & $(2.890 .965,48)$ \\
\hline 3 & Kab. Trenggalek & $25.155 .745,77$ & $24.909 .076,63$ & $246.669,14$ \\
\hline 4 & Kab. Tulungagung & $40.975 .301,99$ & $44.026 .300,20$ & $(3.050 .998,21)$ \\
\hline 5 & Kab. Blitar & $59.833 .621,76$ & $66.065 .349,05$ & $(6.231 .727,28)$ \\
\hline 6 & Kab. Kediri & $84.254 .303,62$ & $87.787 .815,91$ & $(3.533 .512,28)$ \\
\hline 7 & Kab. Malang & $171.821 .286,53$ & $116.749 .078,65$ & $55.072 .207,88$ \\
\hline 8 & Kab. Lumajang & $43.295 .772,16$ & $46.061 .376,35$ & $(2.765 .604,18)$ \\
\hline 9 & Kab. Jember & $99.349 .890,65$ & $81.276 .895,38$ & $18.072 .995,27$ \\
\hline 10 & Kab. Banyuwangi & $74.342 .151,32$ & $42.841 .931,15$ & $31.500 .220,17$ \\
\hline 11 & Kab. Bondowoso & $27.022 .169,44$ & $29.867 .670,86$ & $(2.845 .501,42)$ \\
\hline 12 & Kab. Situbondo & $23.306 .439,47$ & $22.870 .888,89$ & $435.550,58$ \\
\hline 13 & Kab. Pasuruan & $66.289 .935,23$ & $68.657 .349,44$ & $(2.367 .414,21)$ \\
\hline 14 & Kab. Probolinggo & $103.783 .043,55$ & $91.861 .061,46$ & $11.921 .982,08$ \\
\hline 15 & Kab. Sidoarjo & $85.868 .142,20$ & $85.438 .528,49$ & $429.613,71$ \\
\hline 16 & Kab. Mojokerto & $64.402 .464,06$ & $72.346 .756,32$ & $(7.944 .292,26)$ \\
\hline 17 & Kab. Jombang & $48.339 .252,32$ & $54.011 .385,88$ & $(5.672 .133,56)$ \\
\hline 18 & Kab. Nganjuk & $42.633 .704,81$ & $46.557 .700,70$ & $(3.923 .995,89)$ \\
\hline 19 & Kab. Madiun & $31.442 .667,44$ & $34.568 .065,54$ & $(3.125 .398,09)$ \\
\hline 20 & Kab. Magetan & $15.998 .880,89$ & $18.496 .946,65$ & $(2.498 .068,76)$ \\
\hline 21 & Kab. Ngawi & $25.525 .890,98$ & $26.830 .442,67$ & $(1.304 .531,69)$ \\
\hline 22 & Kab. Bojonegoro & $45.820 .023,02$ & $41.404 .540,86$ & $4.415 .482,16$ \\
\hline 23 & Kab. Tuban & $37.729 .195,51$ & $35.627 .737,17$ & $2.101 .458,34$ \\
\hline 24 & Kab. Lamongan & $52.257 .762,88$ & $55.866 .010,59$ & $(3.608 .247,71)$ \\
\hline 25 & Kab. Gresik & $54.445 .815,94$ & $56.067 .976,65$ & $(1.622 .160,95)$ \\
\hline 26 & Kab. Bangkalan & $36.136 .851,94$ & $38.784 .292,43$ & $(2.647 .440,49)$ \\
\hline 27 & Kab. Sampang & $26.119 .277,31$ & $27.752 .819,19$ & $(1.633 .541,88)$ \\
\hline 28 & Kab. Pamekasan & $21.008 .556,09$ & $24.580 .693,48$ & $(3.572 .137,38)$ \\
\hline 29 & Kab. Sumenep & $25.147 .418,68$ & $24.430 .317,03$ & $717.101,65$ \\
\hline 30 & Kota Kediri & $10.011 .347,24$ & $13.281 .515,00$ & $(3.270 .167,77)$ \\
\hline 31 & Kota Blitar & $4.165 .454,43$ & $5.833 .135,66$ & $(1.667 .681,24)$ \\
\hline 32 & Kota Malang & $30.160 .348,50$ & $41.497 .984,22$ & $(11.337 .635,72)$ \\
\hline 33 & Kota Probolinggo & 7.087.281,69 & $11.174 .699,29$ & $(4.087 .417,60)$ \\
\hline 34 & Kota Pasuruan & $7.152 .382,16$ & $9.933 .026,64$ & $(2.780 .644,48)$ \\
\hline 35 & Kota Mojokerto & $4.491 .845,10$ & $5.993 .248,10$ & $(1.501 .403,00)$ \\
\hline 36 & Kota Madiun & $5.015 .307,27$ & $6.716 .014,21$ & $(1.700 .706,94)$ \\
\hline 37 & Kota Surabaya & $106.183 .752,85$ & $138.685 .234,56$ & $(32.501 .481,71)$ \\
\hline 38 & Kota Batu & $10.878 .443,16$ & $14.450 .030,08$ & $(3.571 .586,93)$ \\
\hline
\end{tabular}

Sumber: Data ATTN 2011, diolah

\section{Bangkitan Perjalanan dan Tarikan Perjalanan}

Bangkitan pergerakan merupakan jumlah pergerakan yang berasal dari suatu zona atau tata guna lahan menuju ke zona atau tata guna lahan lain yang menjadi destinasi/tujuan. Tarikan pergerakan merupakan jumlah pergerakan yang tertarik/bergerak ke suatu guna lahan atau zona. Pergerakan lalu lintas merupakan fungsi tata guna lahan yang menghasilkan pergerakan lalu lintas (Tamin 2000, 40). tata guna lahan tingkat provinsi dijabarkan dalam RTRW provinsi.

Pergerakan lalu lintas dalam penelitian ini dibedakan menurut jenis muatan yang diangkut; yaitu muatan barang dan muatan manusia (penumpang). 
Tabel 2 menunjukkan total bangkitan dan tarikan pergerakan barang dari dan menuju zona asal dan zona tujuan menurut kabupaten/kota di Provinsi Jawa Timur.

Pada Tabel 2 dapat dilihat bahwa perbedaan bangkitan dengan tarikan ada yang positif dan ada yang negatif. Secara keseluruhan terdapat 10 daerah yang memiliki perbedaan positif, artinya bahwa lebih banyak muatan barang yang keluar dibanding yang datang. Kesepuluh daerah tersebut adalah Kabupaten Trenggalek, Kabupaten Malang, Jember, Banyuwangi, Situbondo, Pasuruan, Sidoarjo, Bojonegoro, Tuban, dan Kabupaten Sumenep.

Tabel 2 juga menunjukkan bahwa total pergerakan antar-zona di dalam wilayah Provinsi Jawa Timur untuk muatan barang adalah sebesar 1.659.910.335 ton. Kabupaten Malang menjadi sumber pergerakan barang terbesar di Jawa Timur, diikuti oleh Kota Surabaya, Kabupaten Pasuruan, Kabupaten Jember dan Kabupaten Sidoarjo. Sementara itu Kota Blitar, Kota Mojokerto, Kota Madiun, Kota Probolinggo dan Kota Pasuruan menjadi daerah yang menjadi sumber pergerakan terkecil. Namun menjadi sumber pergerakan terkecil tidak berarti bahwa daerah ini menjadi daerah tujuan terbesar. Enam daerah yang menjadi zona tujuan terbesar pergerakan barang di Jawa Timur berturut-turut adalah Kota Surabaya, Kabupaten Malang, Kabupaten Pasuruan, Kabupaten Kediri, Kabupaten Sidoarjo dan Kabupaten Jember. Ternyata daerahdaerah tujuan terbesar ini sekaligus juga menjadi daerah-daerah sumber pergerakan barang terbesar. Intensitas pergerakan barang antar kabupaten/kota ini mencerminkan besarnya arus lalu lintas yang bergerak di wilayah ini. Hal ini juga dapat diartikan bahwa ada saling ketergantungan di antara daerah-daerah ini. Demikian juga yang terjadi pada zona-zona tujuan terkecil. Tujuh zona terkecil berturut-turut adalah Kota Blitar, Kota Mojokerto, Kota Madiun, Kota Pasuruan, Kota Probolinggo, Kota Kediri dan Kota Batu. Daerah-daerah yang menjadi zona tujuan pergerakan barang terkecil ini juga sekaligus juga menjadi daerah-daerah yang menjadi zona asal (sumber) pergerakan barang terkecil.

Lima daerah yang menjadi tujuan utama pergerakan barang ditunjukkan dalam Lampiran 1. Berdasarkan pada Lampiran 1, terlihat nama Kabupaten Malang sering muncul sebagai 5 daerah tujuan pergerakan barang terbesar dari daerah kabupaten/kota lainnya (34 kali). Daerah-daerah yang menetapkan Kabupaten Malang sebagai daerah tujuan terbesar ada sejumlah 2 daerah yaitu Kota Malang dan Kota Batu; yang menjadikan Kabupaten Malang sebagai daerah tujuan pergerakan barang terbesar kedua ada sebanyak 10 daerah yaitu Kabupaten Pacitan, Bondowoso, Nganjuk, Ngawi, Bojonegoro, Tuban, Kota Kediri, Kota Blitar, dan Kota Probolinggo. Sementara yang menempatkan Kabupaten Malang sebagai terbesar ketiga ada sejumlah 12 daerah, yang menempatkan sebagai terbesar keempat ada 7 daerah dan yang menempatkan sebagai daerah tujuan terbesar kelima ada 3 daerah.

Daerah yang menjadi lima besar tujuan pergerakan barang selanjutnya adalah Kota Surabaya, Kabupaten Kediri dan Kabupaten Pasuruan. Daerah yang memposisikan Kota Surabaya sebagai tujuan pergerakan barang terbesar ada sejumlah 9 daerah, yang menempatkan sebagai tujuan terbesar kedua sebanyak 3 daerah, yang menempatkan sebagai tujuan terbesar ketiga, keempat dan kelima berturut-turut sejumlah 3 daerah, 5 daerah dan 3 daerah. Sembilan daerah yang menempatkan Kota Surabaya sebagai tujuan utama pergerakan barang adalah: 1) Kabupaten Probolinggo; 2) Kabupaten Pasuruan; 3) Kabupaten Sidoarjo; 4) Kabupaten Lamongan; 5) Kabupaten Gresik; 6) 
Kabupaten Bangkalan; 7) Kabupaten Sampang; 8) Kabupaten Pamekasan; 9) Kabupaten Sumenep.

Sementara yang menjadikan Kota Surabaya sebagai tujuan pergerakan barang terbesar kedua adalah Kabupaten Jombang, Kota Pasuruan dan Kota Mojokerto. Daerah yang menempatkan Kota Surabaya sebagai tujuan terbesar ketiga dari pergerakan barang adalah Kabupaten Mojokerto, Bojonegoro dan Tuban.

Perhitungan menggunakan cara pengurutan secara vertikal dari Matriks Aasal Tujuan (MAT) menghasilkan temuan mengenai 'distributor' pemasok bangkitan pergerakan barang. Daerah-daerah yang memiliki ranking 1 s/d 5 terbesar berturut-turut adalah Kabupaten Malang (sejumlah 37), Kabupaten Pasuruan (sejumlah 22), Kota Surabaya (sejumlah 17), Kabupaten Kediri (sejumlah 16) dan Kabupaten Jember (sejumlah 15). Artinya bahwa Kabupaten Malang berhasil menjadi pemasok utama bagi 37 daerah lainnya di Jawa Timur; Kabupaten Pasuruan menjadi pemasok utama bagi 22 daerah lainnya; Kota Surabaya menjadi pemasok utama bagi 17 daerah lainnya; Kabupaten Kediri dan Kabupaten Jember masing-masing menjadi pemasok utama bagi 16 dan 15 daerah lainnya di Jawa Timur.

Berdasarkan pada data-data pergerakan barang dan manusia, dapat dilakukan analisis interaksi pergerakan barang/manusia antar wilayah kabupaten/kota secara bilateral dalam Provinsi Jawa Timur. Kabupaten/kota yang terdapat di Provinsi Jawa Timur sejumlah 38 wilayah, sehingga untuk dapat melakukan analisis interaksi bilateral, maka perlu diambil 2 kombinasi dari 38 wilayah kabupaten/kota.

Apabila diambil kombinasi 2 kabupeten/kota dari 38 kabupaten/kota yang ada, maka akan terdapat kombinasi sejumlah 703 kombinasi.Jumlah kombinasi ini (703) terlalu banyak untuk dianalisis satu persatu. Oleh karena itu pada pembahasan bagian ini peneliti hanya membatasi pada hubungan antar daerah yang sesuai dengan pembagian Wilayah Pengembangan (WP) dalam pola srtuktur ruang wilayah Provinsi Jawa Timur sebagai bagian dari RTRWP Jawa Timur. Adapun Wilayah Pengembangan dalam RTRWP Jawa Timur terdiri dari 8 bagian, yaitu:

1. WP Gerbangkertosusila Plus, terdiri dari: Kota Surabaya, Kabupaten Tuban, Lamongan, Bojonegoro, Gresik, Sidoarjo, Kabupaten Mojokerto, Kabupaten Jombang, Kabupaten Pasuruan, Kota Pasuruan, Kabupaten Bangkalan, Kabupaten Sampang, Kabupaten Pamekasan, dan Kabupaten Sumenep.

2. WP Malang Raya, terdiri dari Kota Malang, Kota Batu dan Kabupaten Malang.

3. WP Madiun dan sekitarnya, terdiri dari: Kota Madiun, Kabupaten Madiun, Kabupaten Ponorogo, Kabupaten Magetan, Kabupaten Pacitan dan Kabupetn Ngawi.

4. WP Kediri dan sekitarnya, terdiri dari: Kota Kediri, Kabupaten Kediri, Kabupaten Nganjuk, Kabupaten Trenggalek, dan Kabupaten Tulungagung.

5. WP Probolinggo-Lumajang, terdiri dari: Kota Probolinggo, Kabupaten Probolinggo, dan Kabupaten Lumajang.

6. WP Blitar terdiri dari: Kota Blitar dan Kabupaten Blitar.

7. WP Jember dan sekitarnya, terdiri dari: Kabupaten Jember, Bondowoso, dan Situbondo.

8. WP Banyuwangi, meliputi Kabupaten Banyuwangi.

Intensitas pergerakan barang dalam suatu WP, relatif lebih intensif dibanding 
dengan daerah lain. Dalam WP Gerbangkertosusila Plus misalnya, pergerakan dari Kabupaten Gresik paling banyak menuju ke Kota Surabaya, Lamongan, Sidoarjo, Kabupaten Malang dan Kabupaten Mojokerto. Sedangkan pergerakan yang memasuki Kabupaten Gresik banyak berasal dari Kota Surabaya, Lamongan, Kabupaten Malang, Kabupaten Pasuruan dan Kabupaten Mojokerto. Selain Kabupaten Malang, intensitas pergerakan barang di Kabupaten Gresik banyak terjadi dalam kabupaten/kota yang tercakup dalam WP ini. Beberapa hubungan yang intensif, yang terjadi dalam WP ini antara lain:

1. Kota Surabaya - Kabupaten Gresik; dengan posisi ekspor neto pada Kabupaten Gresik sebesar 2.190.956 ton.

2. Kota Surabaya - Kabupaten Mojokerto; dengan posisi ekspor neto pada Kabupaten Mojokerto sebesar 647.458 ton;

3. Kota Surabaya - Kabupaten Sidoarjo; dengan posisi ekspor neto pada Kabupaten Mojokerto sebesar 7.484.536 ton;

4. Kota Surabaya - Kabupaten Lamongan; dengan posisi ekspor neto pada Kota Surabaya sebesar 1.664.050 ton;

5. Kota Surabaya - Kabupaten Bangkalan; dengan posisi ekspor neto pada Kabupaten Bangkalan sebesar 473.267 ton;

6. Kabupaten Sidoarjo - Kabupaten Gresik; dengan posisi ekspor neto pada Kabupaten Gresik sebesar 1.837.153 ton;

7. Kabupaten Gresik - Kabupaten Mojokerto; dengan posisi ekspor neto pada Kabupaten Mojokerto sebesar 220.767 ton.

Sementara itu berdasarkan perhitungan menggunakan cara pengurutan secara vertikal dari Matriks Asal Tujuan (MAT), menghasilkan temuan mengenai 'distributor' pemasok bangkitan pergerakan barang. Daerah-daerah yang memiliki ranking $1 \mathrm{~s} / \mathrm{d} 5$ terbesar (lihat Lampiran 2), berturut-turut adalah Kabupaten Malang (sejumlah 37), Kab. Pasuruan (sejumlah 22), Kota Surabaya (sejumlah 17), Kab. Kediri (sejumlah 16) dan Kab. Jember (sejumlah 15). Artinya bahwa Kabupaten Malang berhasil menjadi pemasok utama bagi 37 daerah lainnya di Jawa Timur; Kabupaten Pasuruan menjadi pemasok utama bagi 22 daerah lainnya; Kota Surabaya menjadi pemasok utama bagi 17 daerah lainnya; Kabupaten Kediri dan Kabupaten Jember masing-masing menjadi pemasok utama bagi 16 dan 15 daerah lainnya di Jawa Timur.

\section{Ketimpangan Transportasi Barang}

Pergerakan barang di suatu daerah terdiri dari arus pergerakan muatan barang keluar dan juga arus pergerakan muatan barang yang masuk ke suatu wilayah. Sebelum bergerak ke luar daerah, muatan-muatan yang diangkut ini berjalan di dalam daerahnya, sehingga semakin banyak angkutan, maka jalan akan semakin padat. Kepadatan lalu lintas ini tergantung juga pada tersedianya ruang untuk bergerak. Ruang lalu lintas dalam transportasi darat dapat tercermin dari panjang jalan yang dibangun. Kepadatan lalu lintas darat dapat diukur dengan volume muatan dibagi dengan panjang jalan.

Kepadatan lalu lintas barang dapat terjadi karena banyaknya muatan yang diangkut, ataupun juga karena sedikitnya bangunan jalan, sehingga perbandingan antara volume muatan dengan panjang jalan menjadi besar. Di Kabupaten Malang, volume muatan barang yang diangkut relatif sangat tinggi, namun karena infrastruktur jalan relatif cukup memadai, sehingga tingkat kepadatan 'hanya' menempati urutan 7 untuk muatan keluar dan 13 untuk muatan masuk (lihat Lampiran 3). Di sisi lain, Kabupaten Jember, Kabupaten 
Banyuwangi dan Kabupaten Blitar infrastruktur jalan yang dibangun relatif 'kurang' untuk menopang volume lalu lintas sehingga tingkat kepadatannya sangat tinggi. Sementara daerah yang memiliki kepadatan lalu lintas barang relatif rendah antara lain: Kabupaten Sumenep, Kota Madiun, Kabupaten Pacitan, Kota Blitar dan Kabupaten Situbondo.

Variasi tingkat kepadatan lalu lintas barang di daerah kabupaten/kota di Jawa Timur berkisar antara $12.000-390.000$ ton/km. Perbedaan yang cukup jauh ini menunjukkan adanya ketimpangan dalam kepadatan arus lalu lintas barang. Seberapa jauh ketimpangan yang terjadi selanjutnya diukur dengan pendekatan indeks variasi dari Williamson. Dengan menggunakan rumus:

$$
V_{w}=\frac{\sqrt{\sum_{i=1}^{n}\left(t_{i}-\bar{t}\right)^{2}\left(\frac{j_{i}}{J}\right)}}{\bar{t}}
$$

Maka indeks ketimpangan transportasi barang dapat diukur, yaitu sebesar:

$$
V_{w}=\frac{\sqrt{10.136 .003 .246}}{143.636,29}=0,7
$$

Indeks ketimpangan sebesar 0,7 menggambarkan adanya ketimpangan yang cukup tinggi, antara daerah-daerah yang lalu lintas barangnya relatif sepi, dengan daerah-daerah yang lalu lintas barangnya relatif 'ramai'.

\section{Ketimpangan Transportasi Penumpang/Orang}

Pergerakan lalu lintas di jalan tidak hanya berupa pergerakan barang saja, namun juga pergerakan manusia/orang. Dengan membandingkan volume jumlah orang yang melakukan perjalanan di suatu wilayah dengan panjang jalan di wilayah tersebut, maka dapat ditemukan tingkat kepadatan arus perjalanan orang rata-rata setiap kilometer jalan. Tingkat kepadatan arus lalu lintas orang/penumpang di daerah kabupaten/kota ditunjukkan dalam Lampiran 4.

Pada Lampiran 4 terlihat bahwa ada kecenderungan wilayah-wilayah kabupaten/kota yang memiliki tingkat kepadatan lalu lintas orang keluar tinggi juga disertai dengan tingginya kepadatan arus lalu lintas orang yang memasuki wilayah, dan sebaliknya. Daerah-daerah yang memiliki tingkat kepadatan lalu lintas orang relatif tinggi antara lain: 1) Kabupaten Jember; 2) Kota Malang; 3) Kabupaten Blitar; 4) Kabupaten Banyuwangi; 5) Kabupaten Situbondo; 6) Kabupaten Gresik; 7) Kota Pasuruan; 8) Kabupaten Jombang; 9) Kota Surabaya; 10) Kabupaten Lamongan; 11) Kabupaten Sidoarjo; 12) Kabupaten Mojokerto.

Daerah-daerah yang mempunyai arus lalu lintas muatan barang dengan tingkat kepadatan tinggi relatif sama dengan daerah-daerah yang mempunyai arus padat pada lalu lintas muatan orang. Dapat dikatakan bahwa kepadatan arus lalu lintas barang seiring dengan arus kepadatan lalu lintas orang.

Namun demikian indeks ketimpangan transportasi diukur secara terpisah antara ketimpangan transportasi barang dengan ketimpangan transportasi orang. Dengan menggunakan indeks variasi Williamson, diperoleh indeks transportasi untuk lalu lintas penumpang adalah:

$$
V_{w}=\frac{\sqrt{1 \cdot 433.869 .990}}{57.294}=0,66
$$

Indeks ketimpangan transportasi orang diperoleh sebesar 0,66. Angka ini tidak berbeda jauh dari indeks ketimpangan transportasi barang sebesar 0,7. Artinya dalam arus lalu lintas orang/penumpang di Jawa Timur terdapat ketimpangan antar daerah kabupaten/kota. 
Hasil perhitungan menunjukkan bahwa daerah-daerah berikut ini memiliki tingkat kepadatan transportasi orang maupun barang yang tinggi (masuk 9 besar): 1) Kabupaten Blitar; 2) Kabupaten Jember; 3) Kabupaten Banyuwangi; 4) Kabupaten Situbondo; 5) Kabupaten Jombang; 6) Kabupaten Lamongan; 7) Kabupaten Gresik; 8) Kota Malang; 9) Kota Surabaya.

Kesembilan daerah di atas termasuk dalam wilayah dengan tingkat kepadatan lalu lintas tertinggi, baik untuk angkutan barang maupun angkutan orang. Sementara Kabupaten Malang termasuk daerah dengan kepadatan tinggi pada pengangkutan barang, sebaliknya di Kota Pasuruan termasuk dalam daerah dengan tingkat kepadatan tinggi pada pergerakan orang.

Rata-rata tingkat kepadatan lalu lintas di Jawa Timur adalah sebesar 57.294 orang $/ \mathrm{km}$ untuk pengangkutan orang dan 143.636 ton $/ \mathrm{km}$ untuk pengangkutan barang. Apabila digambarkan posisi masing-masing wilayah terhadap rata-rata provinsi berdasarkan tingkat kepadatan transportasi barang dan tingkat kepadatan transportasi orang, maka bisa dideskripsikan tipologi transportasi Provinsi Jawa Timur sebagai berikut:

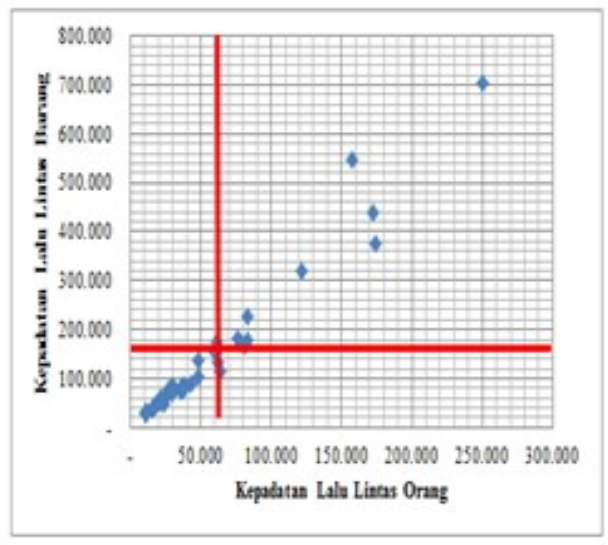

Gambar 1

Tipologi Transportasi

Gambar 1 menunjukkan bahwa sebagian besar kabupaten/kota di Jawa Timur berada pada posisi di bawah rata-rata kepadatan lalu lintas provinsi baik untuk lalu lintas barang maupun orang. Sebagian yan lain berada pada posisi di atas rata-rata provinsi baik untuk kepadatan lalu lintas barang maupun lalu lintas orang. Terlihat ada hubungan antara kepadatan lalu lintas barang dengan kepadatan lalu lintas orang. Semakin tinggi kepadatan lalu lintas orang, semakin tinggi pula tingkat kepadatan lalu lintas barang.

\section{Ketimpangan Wilayah}

Secara umum, lebih banyak daerah kabupaten/kota yang memiliki PDRB/kapita di bawah rata-rata provinsi. Sementara ada satu daerah yang menonjol yaitu Kota Kediri, yang memiliki nilai PDRB/kapita jauh malampaui PDRB/kapita rata-rata provinsi. Enam daerah lainnya yang memiliki nilai PDRB/kapita di atas rata-rata provinsi adalah Kota Surabaya, Kota Malang, Kabupaten Gresik, Kabupaten Sidoarjo, Kota Madiun dan Kota Mojokerto. Perbedaan yang cukup menyolok ini mengindikasikan adanya ketimpangan wilayah di Provinsi Jawa Timur.Apabila daerah-daerah ini diklasifikasikan mengikuti tipologi Klassen, yang dikelompokkan berdasarkan PDRB/kapita dan tingkat pertumbuhan ekonominya, maka diperoleh gambaran sebagai berikut: 


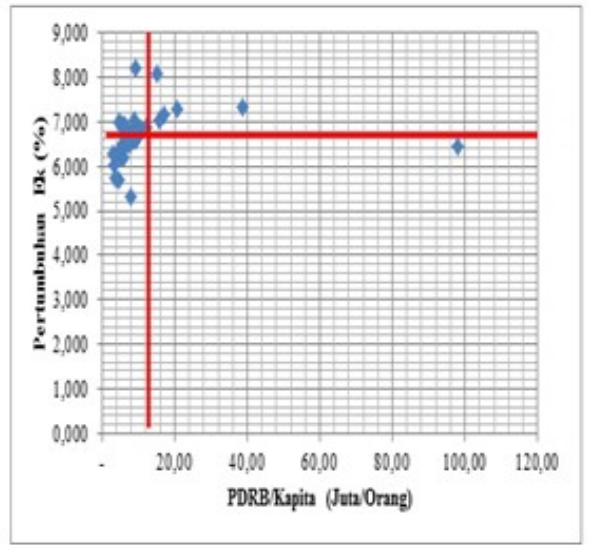

Gambar 2

Tipologi Klassen berikut:

Daerah-daerah yang termasuk dalam tipe I, II, III, dan IV adalah sebagai

I. Daerah cepat maju dan cepat tumbuh: Kota Surabaya, Kota Malang, Kabupaten Gresik, Kabupaten Sidoarjo, Kota Madiun dan Kota Mojokerto.

II. Daerah maju tapi tertekan:Kediri

III. Daerah berkembang cepat: Kabupaten Jember; Kab. Banyuwangi; Kab. Situbondo; Kab. Pasuruan; Kab. Mojokerto; Kab. Nganjuk; Kab. Magetan; Kab. Ngawi; Kab. Tuban; Kab. Lamongan; Kota Probolinggo dan Kota Batu.

IV. Daerah relatif tertinggal adalah daerah yang memiliki tingkat pertumbuhan ekonomi dan pendapatan perkapita yang rendah, yang meliputi: Kabupaten Pacitan;Kab. Ponorogo, Kab. Trenggalek; Kab. Tulungagung; Kab. Blitar; Kab. Kediri; Kab. Malang; Kab. Lumajang; Kab. Bondowoso; Kab. Probolinggo; Kab. Jombang; Kab. Madiun; Kab. Bojonegoro; Kab. Bangkalan; Kab. Sampang; Kab. Pamekasan; Kab. Sumenep; Kota Blitar; Kota Pasuruan.

Berdasarkan perhitungan mengikuti metode Klassen, ternyata masih banyak daerah-daerah di Jawa Timur yang tergolong dalam klasifikasi daerah relatif tertinggal. Sementara yang tergolong dalam daerah cepat maju dan cepat tumbuh ada 6 daerah. Keadaan ini memerlukan perhatian yang lebih intensif untuk dapat mengembangkan perekonomian daerah.

\section{Pengaruh Transportasi terhadap Kesejahteraan}

Perhitungan untuk mengestimasi pengaruh transportasi terhadap kesejahteraan dilakukan dengan cara mencari persamaan regresi antara variabel transportasi yang didekati dengan intensitas kepadatan muatan barang dan orang terhadap indikator kesejahteraan yaitu Indeks Pembangunan Manusia (IPM). Selain variabel transportasi, variabel bebas yang digunakan adalah kemiskinan dan Pendapatan Regional Bruto per Kapita. Perhitungan yang dilakukan dengan program SPSS menghasilkan hasil persamaan regresi berikut: $L Y=1,867-0,045 L X_{1}+0,33 L X_{2}-0,091 L X_{3}+0,023 L X_{4}$ $R^{2}=0,672$ 
Persamaan di atas memberikan hasil koefisien determinasi sebesar 0,672 yang artinya bahwa keempat variabel bebas dapat dipercaya mempengaruhi tingkat kesejahteraan yang diukur dengan IPM sebesar $67,2 \%$. Adapun nilai $F$ sebesar 19,624 > F kritis menunjukkan bahwa pengaruh dari keempat variabel tersebut terhadap kesejahteraan secara bersama-sama dapat diterima secara statistik (signifikan). Namun demikian, apabila dilihat secara parsial dengan mengambil tingkat signifikansi $5 \%$, maka semua variabel tidak signifikan secara statistik kecuali kemiskinan. Variabel PDRB/kapita menjadi signifikan apabila tingkat signifikansinya $10 \%$. Banyaknya variabel bebas yang tidak signifikan ini bisa disebabkan karena adanya ketidaksesuaian dengan asumsi klasik yang digunakan pada saat perhitungan estimasi.

Dari hasil analisis korelasi parsial antar variabel, terlihat adanya korelasi yang cukup erat dan signifikan antara variabel bebas $X_{1}$ (kepadatan transportasi barang) dengan $X_{2}$ (kepadatan transportasi orang) dan antara $X_{3}$ (tingkat kemiskinan) dengan $\mathrm{X}_{4}$ (PDRB/kapita).

Adanya korelasi yang cukup kuat antar variabel bebas membuat estimasi koefisien parameter menjadi bias yang menyebabkan variabel bebasnya menjadi tidak signifikan. Hal ini bisa diatasi dengan menghilangkan salah satu variabel yang terindikasi mengandung multikolinearitas. Variabel yang paling tidak signifikan adalah variabel kepadatan transportasi orang. Oleh karena itu variabel ini dihilangkan dari model, yang menghasilkan persamaan:

$L Y=1,851-0,013 L X_{1}-0,093 L X_{3}+0,025 L X_{4}$ $\mathrm{R}^{2}=0,668$

Model persamaan ini memberikan hasil yang lebih baik, terlihat dari nilai koefisien determinasi sebesar 0,668 dan jumlah variabel bebas yang signifikan bertambah yaitu PDRB/kapita selain tingkat kemiskinan. Dengan koefisien determinasi sebesar ini memberikan pengertian bahwa model ini dapat dipercaya $66,8 \%$. Nilai $\mathrm{F}$ diperoleh sebesar 22,799 > F kritis menunjukkan bahwa secara bersama-sama ketiga variabel bebas berpengaruh terhadap variabel tak bebas. Pengujian secara parsial menyimpulkan bahwa variabel kepadatan transportasi tidak signifikan secara statistik, artinya bahwa secara sendiri-sendiri kepadatan transportasi tidak berpengaruh pada kesejahteraan yang diukur dengan IPM. Namun tingkat kemiskinan dan PDRB/kapita masing-masing dapat mempengaruhi IPM. Apabila terjadi kenaikan tingkat kemiskinan sebesar 1\%, akan membuat IPM menurun sebesar 0,093\%, dan apabila PDRB/kapita naik sebesar $1 \%$ akan meningkatkan IPM sebesar 0,025\%. Apabila dibandingkan antara kedua variabel ini maka tingkat kemiskinan lebih banyak mempengaruhi kesejahteraan yang diukur dengan IPM.

\section{PENUTUP}

Ada 10 daerah yang menjadi pengekspor neto muatan barang. Kesepuluh daerah tersebut adalah: Kabupaten Trenggalek, Kabupaten Malang, Kabupaten Jember, Kabupaten Banyuwangi, Kabupaten Situbondo, Kabupaten Pasuruan, Kabupaten Sidoarjo, Kabupaten Bojonegoro, Kabupaten Tuban, dan Kabupaten Sumenep.

Kabupaten Malang menjadi sumber pergerakan barang terbesar di Jawa Timur, diikuti oleh Kota Surabaya, Kabupaten Pasuruan, Kabupaten Jember dan Kabupaten Sidoarjo. Sementara itu Kota Blitar, Kota Mojokerto, Kota Madiun, Kota Probolinggo dan Kota Pasuruan menjadi daerah yang menjadi sumber 
pergerakan terkecil.

Di samping sebagai sumber pergerakan terbesar, Kabupaten Malang juga sering menjadi daerah tujuan pergerakan barang terbesar dari daerah kabupaten/kota lainnya. Daerah-daerah yang menetapkan Kabupaten Malang sebagai daerah tujuan terbesar ada sejumlah 2 daerah yaitu Kota Malang dan Kota Batu; yang menjadikan Kabupaten Malang sebagai daerah tujuan pergerakan barang terbesar kedua ada sebanyak 10 daerah yaitu Kabupaten Pacitan, Bondowoso, Nganjuk, Ngawi, Bojonegoro, Tuban, Kota Kediri, Kota Blitar, dan Kota Probolinggo.

Daerah yang menjadi lima besar tujuan pergerakan barang setelah Kabupaten Malang adalah Kota Surabaya, Kabupaten Kediri dan Kabupaten Pasuruan. Daerah yang memposisikan Kota Surabaya sebagai tujuan pergerakan barang terbesar ada sejumlah 9 daerah, yang menempatkan sebagai tujuan terbesar kedua sebanyak 3 daerah, yang menempatkan sebagai tujuan terbesar ketiga, keempat dan kelima berturut-turut sejumlah 3 daerah, 5 daerah dan 3 daerah. Sembilan daerah yang menempatkan Kota Surabaya sebagai zona tujuan utama adalah: Kabupaten Probolinggo, Kabupaten Pasuruan, Kabupaten Sidoarjo, Kabupaten Lamongan, Kabupaten Gresik, Kabupaten Bangkalan, Kabupaten Sampang, Kabupaten Pamekasan dan Kabupaten Sumenep.

Berdasarkan perhitungan mengikuti metode Klassen, ternyata masih banyak daerah-daerah di Jawa Timur yang tergolong dalam klasifikasi daerah relatif tertinggal. Sementara yang tergolong dalam daerah cepat maju dan cepat tumbuh ada 6 daerah. Keenam daerah tersebut adalah: 1) Kota Surabaya; 2) Kota Malang; 3) Kabupaten Gresik; 4) Kabupaten Sidoarjo; 5) Kota Madiun; dan 6) Kota Mojokerto.

Daerah yang tergolong dalam daerah maju tapi tertekan adalah Kota Kediri; sementara yang tergolong dalam daerah berkembang cepat adalah: 1) Kabupaten Jember; 2) Kabupaten Banyuwangi; 3) Kabupaten Situbondo; 4) Kabupaten Pasuruan; 5) Kabupaten Mojokerto; 6) Kabupaten Nganjuk; 7) Kabupaten Magetan; 8) Kabupaten Ngawi; 9) Kabupaten Tuban; 10) Kabupaten Lamongan; 11) Kota Probolinggo dan 12) Kota Batu.

Daerah yang tergolong dalam daerah relatif tertinggal adalah: 1) Kabupaten Pacitan; 2) Kabupaten Ponorogo; 3) Kabupaten Trenggalek; 4) Kabupaten Tulungagung; 5) Kabupaten Blitar; 6) Kabupaten Kediri; 7) Kabupaten Malang; 8) Kabupaten Lumajang; 9) Kabupaten Bondowoso; 10) Kabupaten Probolinggo; 11) Kabupaten Jombang; 12) Kabupaten Madiun; 13) Kabupaten Bojonegoro; 14) Kabupaten Bangkalan; 15) Kabupaten Sampang; 16) Kabupaten Pamekasan; 17) Kabupaten Sumenep; 18) Kota Blitar; 19) Kota Pasuruan.

Kepadatan transportasi dapat mempengaruhi kesejahteraan masyarakat yang diukur dengan IPM hanya apabila bersama-sama dengan faktor-faktor lain seperti kemiskinan dan PDRB/kapita. Namun kepadatan transportasi tidak dapat mempengaruhi kesejahteraan secara parsial. 


\section{DAFTAR PUSTAKA}

2012. Kabupaten/Kota dalam Angka. BPS Kabupaten/Kota 2014. Kabupaten/Kota dalam Angka. BPS Kabupaten/Kota

Adisasmita, Sakti Adji.2011. Jaringan Transportasi, Teori dan Analisis. Yogyakarta: Graha IImu.

Adisasmita, Sakti Adji.2011.Transportasi dan Pengembangan Wilayah. Yogyakarta: Graha IImu.

Bank Indonesia. 2014. Kajian Ekonomi Regional Provinsi Jawa Timur TW II.

Budiartha R.M., Nyoman. 2011. Ekonomi Transportasi, Model Penentuan Lokasi Pelabuhan Berbasis Sektor Pariwisata. Denpasar: Udayana University Press.

Calderon, Cesar dan Serven, Luis. 2004. The Effects of Infrastructure Development on Growth and Income Distribution. World Bank Working Paper Series 3400.

Calderon, Cesar dan Serven, Luis. 2010. Infrastructure in Latin America. PolicyResearch Working Paper Series 5317. The World Bank Office of The Chief Economist Latin America \& The Caribbean Region \& Development Research Group Macroeconomics \& Growth Team. May.

Dinas Perhubungan Provinsi Jawa Timur. 2011. Asal Tujuan Transportasi Nasional (ATTN).

Kamaluddin, Rustian. 2003. Ekonomi Transportasi: Karakteristik, Teori dan Kebijakan. Jakarta: Ghalia Indonesia.

Kuncoro, Mudrajad. 2012. Perencanaan Daerah, Bagaimana Membangun Ekonomi Lokal, Kota dan Kawasan?.Jakarta: Salemba Empat

Kuncoro, Mudrajad. 2013. Mudah Memahami dan Menganalisis/ndikator Ekonomi. Yogyakarta: UPP STIM YKPN.

Litman, Todd. 2012.Understanding Transport Demands and Elasticities, How Prices and Other Factors Affect Travel Behavior. Report. Victoria Transport Policy Institute, 10 September.

Loayza, Norman V dan Odawara, Rei. 2010. Infrastructure and Economic Growth in Egypt. Policy Research Working Paper 5177. The World Bank Middle East \& North Africa Region Social Development Group.

Miro, Fidel. 2005. Perencanaan Transportasi. Jakarta: Erlangga.

Miro, Fidel.2012. Pengantar Sistem Transportasi. Jakarta: Erlangga. 
O'Sullivan, Arthur. 2006.Urban Economics. Sixth Edition, New York: Mc.Graw Hill.

Peraturan Daerah Provinsi Jawa Timur No. 5 tahun 2012 tentang Rencana Tata Ruang Wilayah Provinsi tahun 2011-2030.

Prasetyo, Rindang Bagus dan Firdaus, M. 2009. Pengaruh Infrastruktur Pada Pertumbuhan Ekonomi Wilayah di Indonesia. Jurnal Ekonomi dan Kebijakan Pembangunan2(2): 222-236.

Rustiadi, Ernan, Sunsun Saefulhakim dan Dyah R Panuju. 2008. Perencanaan dan Pengembangan Wilayah. Jakarta: Yayasan Pustaka Obor Indonesia.

Sjafrizal. 2012.Ekonomi Wilayah dan Perkotaan. Jakarta: PT RajaGrafindo Persada.

Tamin, Ofyar Z. 2000. Perencanaan dan Pemodelan Transportasi. Bandung: ITB.

Tarigan, Robinson. 2009. Ekonomi Regional; Teori dan Aplikasi. Jakarta: Bumi Aksara.

Varian, Hal. 2010. Intermediate Microeconomics: A Modarn Approach. Edisi 8. New York: W. W. Norton \& Company. 